\title{
Acil servise nefes darlığı ile başvuran hastalarda yakınma şiddetini değerlendirmede hasta ve hekim algısı
}

\author{
Evaluation of the severity of the complaints in patients presenting to the emergency \\ department with dyspnea: Patient and physician perception
}

\author{
Özlem Dikme, Özgür Dikme
}

Gönderilme tarihi:30.11.2018

Kabul tarihi:18.04.2019

Özet

Amaç:Tanı ve tedavi yönetiminde önemli olan nefes darlığı şiddetini belirlemekte çeşitli ölçekler kullanılmaktadır. Bu çalışmada Modifiye Borg, Medical Research Council ve Vizüel Analog Skalaları kullanılarak nefes darlığı şiddetini tanımlamada hasta ve hekim değerlendirmeleri arasındaki ilişkinin belirlenmesi amaçlandı.

Gereç ve Yöntem:Prospektif, gözleme dayalı, kesitsel yapılan çalışmaya acil servise nefes darlığı yakınmasıyla başvuran 18 yaş üzeri ardışık hastalar alındı. Hastalara nefes darlığı şiddetini belirlemek amacıyla Vizüel Analog ve Borg skalaları üzerinde işaretleme yaptırıldı. Hekimler tarafından da nefes darlığı şiddeti Vizüel Analog ve Medical Research Council skalalarıyla değerlendirildi. Skorlama sonuçlarının birbirleriyle olan ilişkileri incelendi. Bulgular:87 hastanın 43'ü $(\% 49,4)$ erkekti, yaş ortalaması 72,1 $\pm 12,7$ yıldı. Hastalarda Vizüel Analog Skala ile Borg skoru ( $r=0,978, p \leq 0,001)$, hekimlerde ise Vizüel Analog Skala ile Medical Research Council skoru $(r=0,928, p \leq 0,001)$ arasında; hasta ile hekim karşılaştırmalarında ise hasta-hekim Vizüel Analog Skala skorları $(r=0,641, p \leq 0,001)$ ve hasta Borg ile hekim Medical Research Council skorları $(r=0,632, p \leq 0,001)$ arasında anlamlı pozitif korelasyon saptandı. Yaş değerlendirildiğinde; hasta-hekim Vizüel Analog Skala skoru 65 yaş altı $(\mathrm{r}=0,413, p=0,032)$ ve 65 yaş üstü grupta $(\mathrm{r}=0,722, p \leq 0,001)$ anlamlı pozitif korele saptandı. Erkek $(r=0,730$, $p \leq 0,001)$ ve kadın $(r=0,500, p \leq 0,001)$ hastaların değerlendirilmesinde hasta-hekim Vizüel Analog Skala skorları ve yine erkeklerde $(r=0,711, p \leq 0,001)$ ve kadınlarda $(r=0,542, p \leq 0,001)$ hasta Borg skoru ile hekim Medical Research Council Skalası skoru arasında anlamlı pozitif korelasyonlar saptandı.

Sonuç:Acil serviste hasta ve hekim gözüyle nefes darlığı şiddetini değerlendirmede kullanılan Vizüel Analog Skalası, Borg ve Medical Research Council skalaları koreledir. Ancak korelasyon gücü 65 yaş altında ve kadınlarda daha düşüktür.

Anahtar Kelimeler: Acil servis, nefes darlığı, modifiye Borg skalası, vizüel analog skala, Medical Research Council skalası.

Dikme Ö, Dikme Ö. Acil servise nefes darlığı ile başvuran hastalarda yakınma şiddetini değerlendirmede hasta ve hekim algısı. Pam Tıp Derg 2019;12:251-259.

\begin{abstract}
Purpose:Various scales are used to determine the severity of dyspnea. In this study we aimed to determine the relationship between patient-physician evaluations by using modified Borg, Medical Research Council and visual analog scales.

Materials and Methods:This prospective, observational, cross-sectional study included consecutive patients over 18 years who presented with dyspnea to emergency department. The severity was evaluated by patients with using visual analog and Borg scales and by physicians with using visual analog and Medical Research Council Scale.

Results: Of the 87 patients, $43(49.4 \%)$ were male an d the mean age was $72.1 \pm 12.7$ Patients' visual analog scale and Borg scores $(r=0.978, p \leq 0.001)$ and physicians' visual analog scale and Medical Research Council scores $(r=0.928, p \leq 0.001)$, and also, patient-physician visual analog scores $(r=0.641, p \leq 0.001)$ and patients' Borg and physicians' Medical Research Council scores ( $r=0.632, p \leq 0.001)$ were positively corelated. The patientphysician visual analog scores were found positively corelated even in age lower 65 years $(r=0.413, p=0.032)$ and age over 65 years groups $(r=0.722, p \leq 0.001)$. Physicians' and patients' visual analog scores were positive corelated in male $(r=0.730, p \leq 0.001)$ and female $(r=0.500, p \leq 0.001)$. Physicians' Medical Research Council and patients' Borg scores were significant positive corelated in the evaluation of male $(r=0.711, p \leq 0.001)$ and female $(r=0.542, p \leq 0.001)$.

Conclusion:Visual analog scale, Borg and Medical Research Council scales which were used to evaluate the severity of dyspnea in the emergency department are corelated with each other. However, the correlation power is lower in the group of age lower than 65 years and female patients.
\end{abstract}

Özlem Dikme, Uz. Dr. Koç Üniversitesi Tıp Fakültesi Acil Tıp Anabilim Dalı, ISTANBUL, e-posta: ozlemakinci80@yahoo.com (orcid.org/00000002-9739-3925) (Sorumlu yazar)

Özgür Dikme, Uz. Dr. Sağlık Bilimleri Üniversitesi İstanbul Eğitim ve Araştırma Hastanesi Acil Tıp Kliniği, íSTANBUL, e-posta: drozgurdikme@ yahoo.com (orcid.org/0000-0001-6221-7932) 
Key Words: Emergency department, dyspnea, visual analog scale, modified Borg scale, Medical Research Council scale.

Dikme Ö, Dikme Ö. Evaluation of the severity of the complaints in patients presenting to the emergency department with dyspnea: Patient and physician perception. Pam Med J 2019;12:251-259.

\section{Giriş}

Nefes darlığı hastayı hekime götüren en önemli yakınmalardan birisidir. İş göremezliğe kadar gidebilen günlük yaşam aktivitelerinde kısıtlanma, yaşam kalitesinde bozulma ve anksiyetenin sık nedenleri arasında olan nefes darlığı, solumada güçlük hissi ya da solunum sıkıntısı olarak tanımlanır. Hastalar tarafından sıklıkla "soluksuzluk, nefes alamama" şeklinde ifade edilen bu yakınma; Amerikan Toraks Derneği ise nefes darlığını "hoş olmayan veya konforsuz soluk alma hissi ve çeşitli yoğunlukta duyuların oluşturduğu kişisel solunum rahatsızlığı deneyimi” olarak tanımlamıştır [1]. Acil servise nefes darlığı ile gelen hastaların yaklaşık üçte birinin etiyolojisinde kardiyak ve de pulmoner nedenlerden oluştuğu bilinmekle birlikte, nefes darlığı tek bir sistemde ya da patofizyolojik mekanizmada bozulma sonucu değil, pek çok sistemi ilgilendiren sorunlar sonrası gelişebilmektedir [2]. Nefes darlığının altında yatan temel patofizyolojinin saptanması subjektif bir yakınma olan nefes darlığının varlığı ve derecesinin ölçümü için son derece önemlidir. Nefes darlığının derece ve şiddetini ölçmek ya da günlük yaşam üzerine etkisini değerlendirmek için geliştirilmiş çeşitli psikofiziksel ölçekler ve teknikler bulunmaktadır. Psikofiziksel testler, dışarıdan eklenen yüklere karşılık solunumdaki değişikliklerin algılanışını ölçmeye dayanmaktadır. Bu yaklaşım solunuma ait duyumların anlaşıımasında faydalı bulunmuş olsa da teknik ve zamanla ilgili sorunlar nedeniyle kullanımı sınırlanmıştır. Klinik ölçekler ise hastada nefes darlığını oluşturan işin büyüklüğünü belirlemeye yönelmiştir. Literatürde, sübjektif bir yakınma olan nefes darlığının nedenini saptayarak tedavi etmenin yanı sıra derecesinin ölçümünün de önemli olduğu vurgulanmaktadır [3].

Nefes darlığı ölçekleri tek yönlü ve çok yönlü olarak ikiye ayrılmaktadır [3]. Çalışmalara bakıldığında yaygın olarak kullanılan dört adet tek yönlü ölçek ile karşılaşılmaktadır: Vizüel Analog Skalası (VAS), Oksijen Tüketim Diagramı, Modifiye Borg Skalası ve Sözel Derecelendirme Skalası. Bunlar arasında en sık kullanılan tek yönlü ölçekler, Modifiye Borg Skalası ve VAS'dır. Çok yönlü nefes darlığı ölçekleri ise şiddet ile günlük aktivite ve konuşma yanı sıra; korku, depresyon, solunum sırasında harcanan çaba gibi birçok parametreyi de ölçmekte kullanılmaktadır. En sık kullanılan iki ölçek, Bazal Dispne İndeksi/Geçiş Dispne Indeksi ve Medical Research Council Skalası (MRC)'dır.

Nefes darlığının hasta ve hekim tarafından algılanmasındaki ilişki birçok kez çalışmalara konu olmuştur. Bu çalışmada, acil servis başvurularında önemli bir yer kaplayan nefes darlığı yakınmasında erişkin hastalarda yakınma şiddetinin hasta (VAS, Modifiye Borg skalası) ve hekime yönelik (VAS, MRC skalası) değerlendirilerek korelasyonlarının belirlenmesi ve değerlendirme sonuçlarının demografik parametreler, klinik ve sonlanım verileriyle ilişkisinin araştırılması amaçlanmıştır.

\section{Gereç ve yöntem}

Gözleme dayalı, kesitsel, analitik dizayn edilen araştırmaya bölgesel etik kurul onayı alındıktan sonra başlandı (İstanbul Eğitim ve Araştırma Hastanesi Klinik Araştırmalar Etik Kurulu, Tarih: 09/11/2018, Karar no: 1498). Araştırma evrenini, etik kurul onayından sonraki üç ay süresince acil servise nefes darlığı yakınması, ya da nefes yetmezliği, nefes açlığı gibi karşılığı olabilecek ifadeler kullanan 18 yaş üzerindeki tüm erişkin hastalar oluşturdu. Travma olguları, zehirlenmeler, gebe hastalar, gelişte entübe veya arrest olan hastalar ve okuma/yazma bilmeyen, körlüğü olan, bilişsel olarak anlamaya engel teşkil eden psikiyatrik hastalık veya mental durumu bulunan hastalar çalışmadan dışlandı. Yine Modifiye Borg Skalasına göre nefes darlığı yakınmasını yok ya da hafif olarak belirleyen hastalar (Borg<3) çalışma dışında bırakıldı (Tablo 1). Çalışmaya dahil etme kriterlerine uyan hastaların tümü araştırma hakkında bilgilendirildi ve kabul eden hastalardan yazılı onam formu alındı, kabul etmeyen hastalar çalışma dışı bırakıldı. Çalışma hastaları için acil serviste ilk değerlendirme, stabilizasyon ve acil müdahale, resüsitasyon 
Tablo 1. Çalışmaya alınan hastaların özellikleri.

\begin{tabular}{|c|c|c|c|}
\hline & & $\mathrm{n}$ & $\%$ \\
\hline \multirow{2}{*}{ Yaş } & $\leq 65$ & 27 & 31,0 \\
\hline & $>65$ & 60 & 69,0 \\
\hline \multirow{2}{*}{ Cinsiyet } & Erkek & 43 & 49,4 \\
\hline & Kadın & 44 & 50,6 \\
\hline \multirow{2}{*}{ Triaj Kodu } & Kırmızı & 49 & 56,3 \\
\hline & Sarı & 38 & 43,7 \\
\hline \multirow{2}{*}{ Acil Servise Başvuru Şekli } & Ayaktan & 57 & 65,5 \\
\hline & Ambulans & 30 & 34,5 \\
\hline \multirow{2}{*}{$\begin{array}{l}\text { Son } 1 \text { Ay İçinde Nefes Darlığı İle Hastaneye } \\
\text { Başvuru }\end{array}$} & Var & 36 & 41,4 \\
\hline & Yok & 51 & 58,6 \\
\hline \multirow{2}{*}{$\begin{array}{l}\text { Nefes Darlığı Sonrası Hastaneye Yatış Öy- } \\
\text { küsü }\end{array}$} & Var & 36 & 41,4 \\
\hline & Yok & 51 & 58,6 \\
\hline \multirow{2}{*}{ Entübasyon Öyküsü } & Var & 11 & 12,6 \\
\hline & Yok & 76 & 87,4 \\
\hline \multirow{2}{*}{ Kronik Hastalık } & Var & 77 & 88,5 \\
\hline & Yok & 10 & 11,5 \\
\hline \multirow{2}{*}{ Sigara Kullanımı } & Var & 28 & 32,2 \\
\hline & Yok & 59 & 67,8 \\
\hline \multirow{3}{*}{ Kan Basıncı, mmHg } & Hipotansif $(<90 / 60)$ & 6 & 6,9 \\
\hline & Normal (90-139/60-89) & 47 & 54 \\
\hline & Hipertansif ( $\geq 140 / 90)$ & 34 & 39,1 \\
\hline \multirow{2}{*}{ Nabız, atım/dk } & Normal (60-100) & 45 & 51,7 \\
\hline & Taşikardik (>100) & 42 & 48,3 \\
\hline \multirow{2}{*}{ Solunum Sayısı, solunum/dk } & Normal (12-20) & 61 & 70,1 \\
\hline & Taşipne (>20) & 26 & 29,9 \\
\hline \multirow{2}{*}{ Vücut Isısı, ${ }^{\circ} \mathrm{C}$} & Normal (35-38) & 77 & 88,5 \\
\hline & Yüksek (>38) & 10 & 11,5 \\
\hline \multirow{2}{*}{ Periferik Oksijen Saturasyonu, \% } & Düşük $(<90)$ & 26 & 29,9 \\
\hline & Normal (>90) & 61 & 70,1 \\
\hline \multirow{2}{*}{ Akciğer Fizik Muayenesi } & Normal & 10 & 11,5 \\
\hline & Anormal & 77 & 88,5 \\
\hline \multirow{3}{*}{ Sonlanım } & Taburcu & 39 & 44,8 \\
\hline & Servis Yatışı & 30 & 34,5 \\
\hline & Yoğun Bakım Yatışı & 18 & 20,7 \\
\hline \multirow{2}{*}{ Konsültasyon İhtiyacı } & Var & 64 & 73,6 \\
\hline & Yok & 23 & 26,4 \\
\hline \multirow{6}{*}{ Son Tanı } & KOAH/Astım & 17 & 19,5 \\
\hline & Pnömoni & 29 & 33,3 \\
\hline & Akciğer Ödemi & 33 & 37,9 \\
\hline & Akut Koroner Sendrom & 4 & 4,6 \\
\hline & $\begin{array}{l}\text { Pulmoner Tromboem- } \\
\text { boli }\end{array}$ & 2 & 2,3 \\
\hline & Nonspesifik & 2 & 2,3 \\
\hline
\end{tabular}


gibi işlemlerde çalışma sebepli herhangi bir değişiklik uygulanmadı. Acil servis işleyişi olması gerektiği gibi rutininde devam etti.

Acil servise nefes darlığı yakınmasıyla başvuran 18 yaş üzeri ardışık hastalar çalışmaya alındı. Örneklem hesabında, acil servis başvurularının yaklaşık \%6'lık kısmının nefes darlığı şikayetinden kaynaklanıyor olması sebebi ile güven aralığı \%95 olacak şekilde \%95 gücü elde etmek için en az 87 hastanın alınmasına karar verildi. Çalışma hastalarının nefes darlığına yönelik yakınma değerlendirmesi acil servise ilk girişte hasta ve birincil bakımından sorumlu hekimi karşılaştığında her ikisine de eş zamanlı olarak uygulandı. Hastalar nefes darlığı şiddetini belirlemek amacıyla VAS ve Modifiye Borg skorlamaları üzerinde işaretleme yaptılar. Benzer şekilde hastayı ilk karşılayan acil tıp hekimleri de hastadaki nefes darlığı şiddetini VAS ve MRC skorlamaları üzerinden değerlendirdiler. VAS, her olguda hem hasta hem de hekim için ayrı ayrı uygulandı. Yüz milimetrelik bir yatay çizgi üzerinde kalemle işaretleme yapıldı. Bu çizginin $0 \mathrm{~mm}$ noktası nefes darlığı yok, 100 mm noktası ise olabilecek en şiddetli nefes darlığı yakınması idi (Resim 1). Hasta ve hekim birbirlerine kör şekilde ölçek üzerinde o anki solunum sıkıntısının şiddetini bu iki dereceyi kriter alarak işaretlediler. Puanlama, işaretli noktanın cetvel yardımıyla ölçülmesiyle yapıldı. Modifiye Borg Skorlaması'nda ise hastalar derecelerine göre nefes darlığının şiddetini tanımlayan on maddeden oluşan bir skala üzerinde işaretleme yaptılar (Resim 2). MRC skalasında ise, hekim hastanın nefes

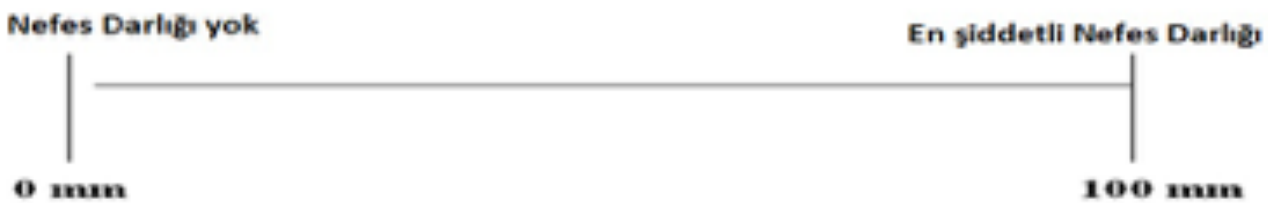

Resim 1. Vizüel Analog Skala (VAS).

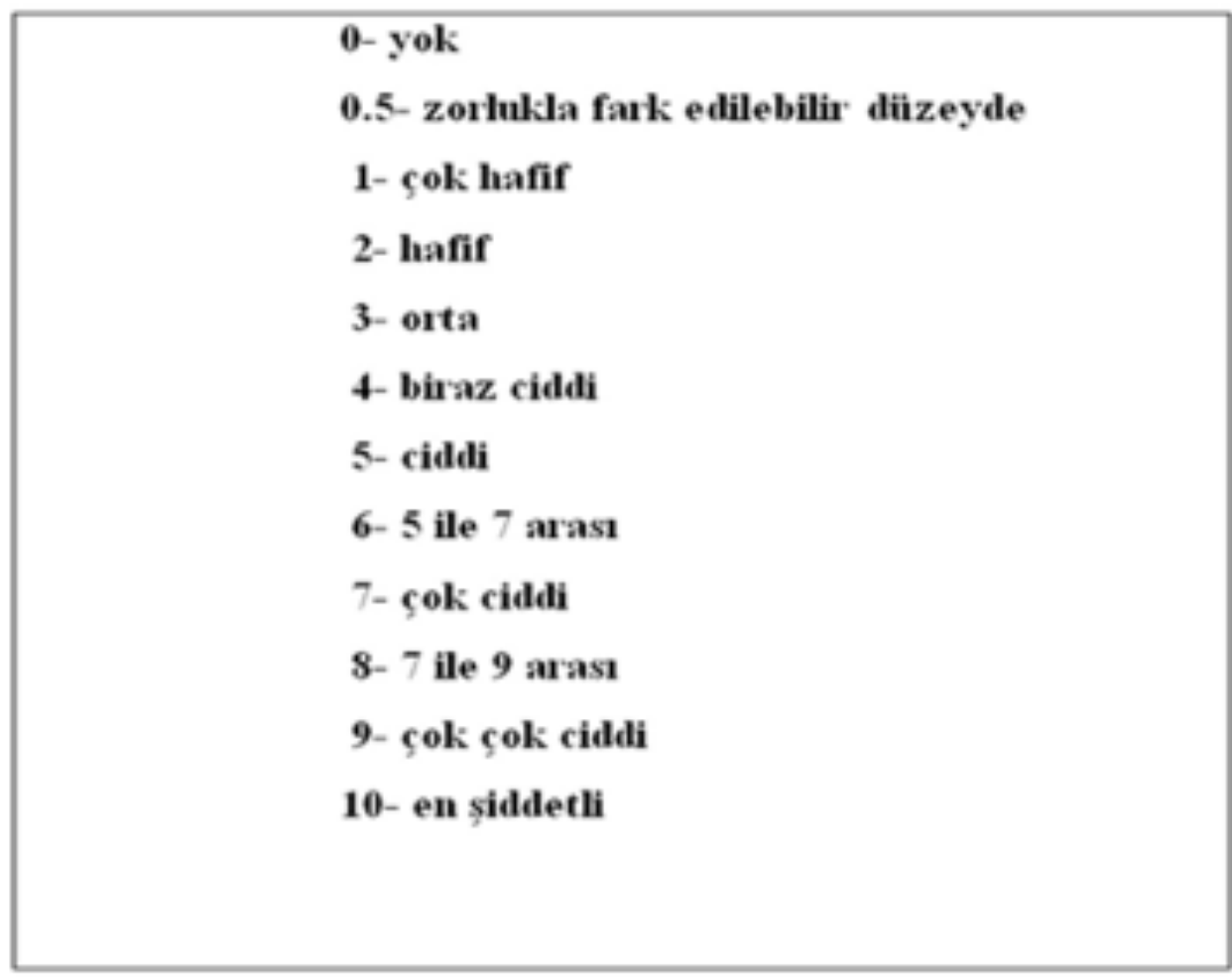

Resim 2. Modifiye Borg Skalası. 


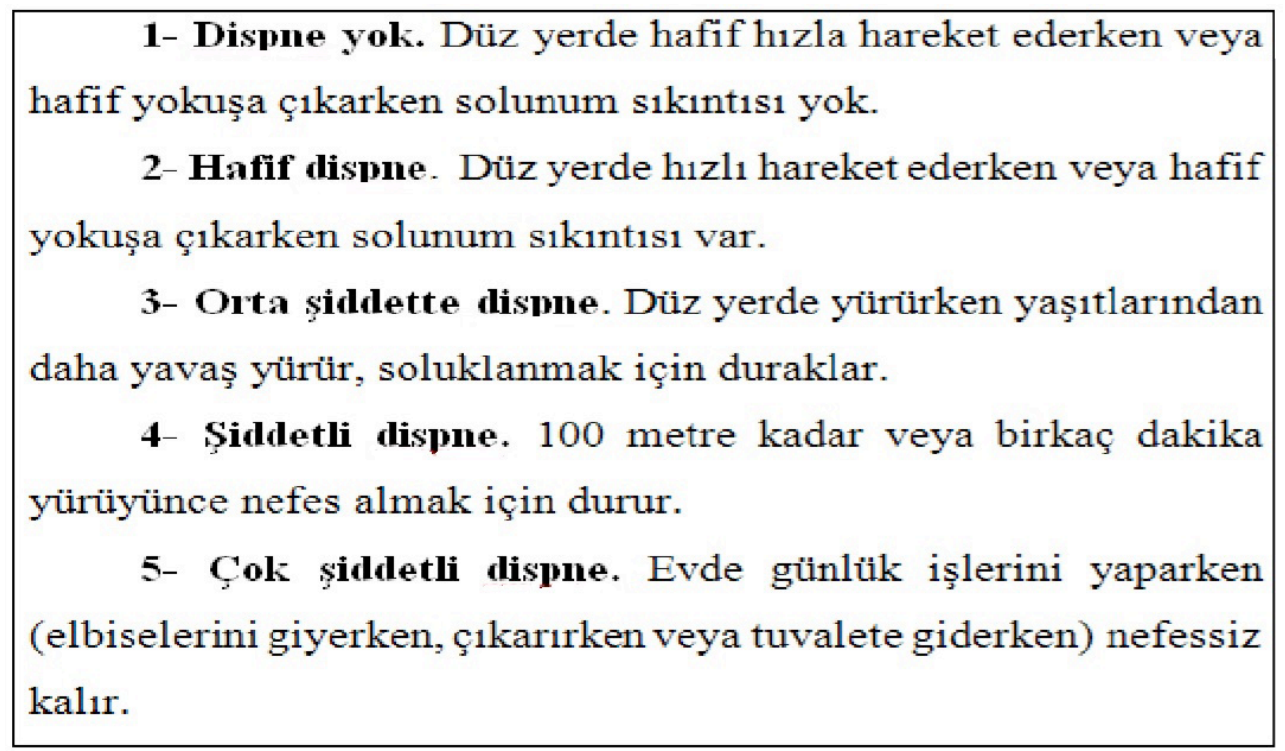

Resim 3. Medical Research Council (MRC) Skalası.

darlığı hissi meydana getiren fiziksel aktivitelere yönelik sorgulamasını skaladaki beş madde üzerinden yaparak, değerlendirdiği hasta için en uygun sonucu işaretledi (Resim 3).

VAS, Borg ve MRC skorları ile belirlenen nefes darlığı şiddetlerinin demografik parametreler, klinik ve sonlanım verileriyle ilişkisi araştırıldı. Tüm analizlerde SPSS 22.0 programı kullanıldı. İstatistiksel yöntem olarak; verilerin tanımlayıcı istatistiklerinde ortalama, standart sapma, medyan en düşük, en yüksek, frekans ve oran değerleri kullanıldı. Değişkenlerin dağılımı Kolmogorov Smirnov test ile ölçüldü. Korelasyon analizinde spearman korelasyon analizi kullanıldı. Anlamlılık düzeyi $p<0,05$ olarak kabul edildi.

\section{Bulgular}

Çalışmaya alınan 87 hastanın yaş ortalaması $72,1 \pm 12,7$ yıl ve hastaların 43'ü $(\% 49,4)$ erkek idi (Tablo 1). Nefes darlığı şiddetinde hasta VAS ortalaması $71,3 \pm 19,9 \mathrm{~mm}$, hekim VAS ortalaması $54,4 \pm 19,7 \mathrm{~mm}$ idi (Tablo 2). Her iki grupta VAS değerleri yaş ve cinsiyetten bağımsızken, kırmızı triyaj kodu (hasta VAS $p=0,001$, hekim VAS $p<0,001$ ) ve hastaların acil servise ambulans ile kabulü (hasta VAS $p=0,029$, hekim VAS $p=0,002$ ) arasında anlamlı ilişki saptandı. Daha önce hastanede nefes darlığı nedeniyle yatış öyküsünün varlığı ile hasta VAS $(p<0,001)$ ve hekim VAS $(p<0,001)$ arasında anlamlı ilişki saptanırken, öyküsünde entübasyon uygulanmış olması, kronik hastalık varlığı ve sigara kullanım öyküsünden iki grup da bağımsız bulundu. Hastaya ait VAS değerleri vital bulgularda kan basıncı ve vücut sıcaklığından bağımsız iken nabız $(p=0,004)$, solunum sayısı $(p=0,009)$ ve SpO2 $(p=0,007)$ ile ilişkili, hekime ait VAS değerleri ise kan basıncı düşüklüğü $(p<0,001)$, nabız $(p=0,005)$, solunum sayısı $(p<0,001)$ ve SpO2 $(p<0,001)$ ile anlamlı ilişkide iken sadece vücut sıcaklığından bağımsız bulundu. Hastalarda akciğer fizik muayene bulgusu varlığı (hasta VAS $p=0,002$, hekim VAS $p<0,001)$, konsültasyon ihtiyacı (hasta VAS $p=0,014$, hekim VAS $p<0,001$ ) ve sonlanımında taburculuğu üzerinde (hasta ve hekim VAS her ikisi için de $p<0,001$ ) anlamlı iken hastanın son tanısı üzerinde hasta VAS anlamsız bulunurken hekim VAS değerleri $\mathrm{KOAH}$ ile akciğer ödemi grupları arasındaki karşılaştırmada $(p=0,008)$ da anlamlı bulundu.

Hastalarda VAS ile Borg skoru ( $r=0,978$, $p \leq 0,001$ ) arasında hekimlerde ise VAS ile MRC skoru $(r=0,928, p \leq 0,001)$ arasında; hasta ile hekim karşılaştırmalarında ise VAS skorları $(r=0,641, p \leq 0,001)$ ve hasta Borg ile hekim MRC skorları $(r=0,632, p \leq 0,001)$ arasında anlamlı pozitif korelasyonlar saptandı (Resim 4). Yaş açısından değerlendirildiğinde; VAS skoru hasta ile hekim arasında 65 yaş altı $(r=0,413$, $p=0,032)$ ve 65 yaş üstü grupta $(r=0,722$, $p \leq 0,001)$ ve hasta Borg skoru ile hekim MRC skoru 65 yaş altı $(r=0,444, p=0,020)$ ve 65 yaş üstü grupta $(r=0,707, p \leq 0,001)$ anlamlı pozitif korele bulundu (Tablo 3). Erkek ( $r=0,730$, $p \leq 0,001)$ ve kadın $(r=0,500, p \leq 0,001)$ hastaların 
değerlendirilmesinde hasta ile hekim VAS skorları ve yine erkeklerde $(r=0,711, p \leq 0,001)$ ve kadınlarda $(r=0,542, p \leq 0,001)$ hasta Borg skoru ile hekim MRC skoru arasında anlamlı pozitif korelasyonlar saptandı (Tablo 3). Taburcu edilen $(r=0,395, p=0,013)$ ve hastaneye yatırılan $(r=0,706, p \leq 0,001)$ hastalarda hasta ile hekim VAS skorları arasında anlamlı pozitif korelasyonlar gözlendi. Taburculukta ( $r=0,273$, $p=0,093$ ) hasta Borg skoru ile hekim MRC skoru arasında korelasyon anlamsızken, yatışta $(r=0,746, p \leq 0,001)$ anlamlı bulundu (Tablo 3$)$.

Başvuru şekli incelendiğinde ayaktan $(r=0,560, p \leq 0,001)$ ve ambulans ile $(r=0,741$, $p \leq 0,001)$ başvurular da hasta ile hekim VAS skorları arasında anlamlı pozitif korelasyon gözlendi. Benzer şekilde ayaktan ( $r=0,537$, $p \leq 0,001)$ ve ambulans $(r=0,729, p \leq 0,001)$ ile başvurularda da hasta Borg skoru ile hekim MRC skoru arasında anlamlı pozitif korelasyon saptandı (Tablo 3). Konsültasyon ihtiyacı olan $(r=0,650, p \leq 0,000)$ ve olmayan $(r=0,528$, $p \leq 0,010)$ gruplarda hasta ve hekim VAS skorları arasında anlamlı pozitif korelasyon var iken; hasta Borg skoru ile hekim MRC skoru konsültasyon ihtiyacı olan grupta anlamlı $(r=0,653, p \leq 0,000)$ korele iken konsültasyon ihtiyacı olmayan grupta $(r=0,412, p \leq 0,051)$ anlamlı değildi (Tablo 3). Hem hasta ile hekim
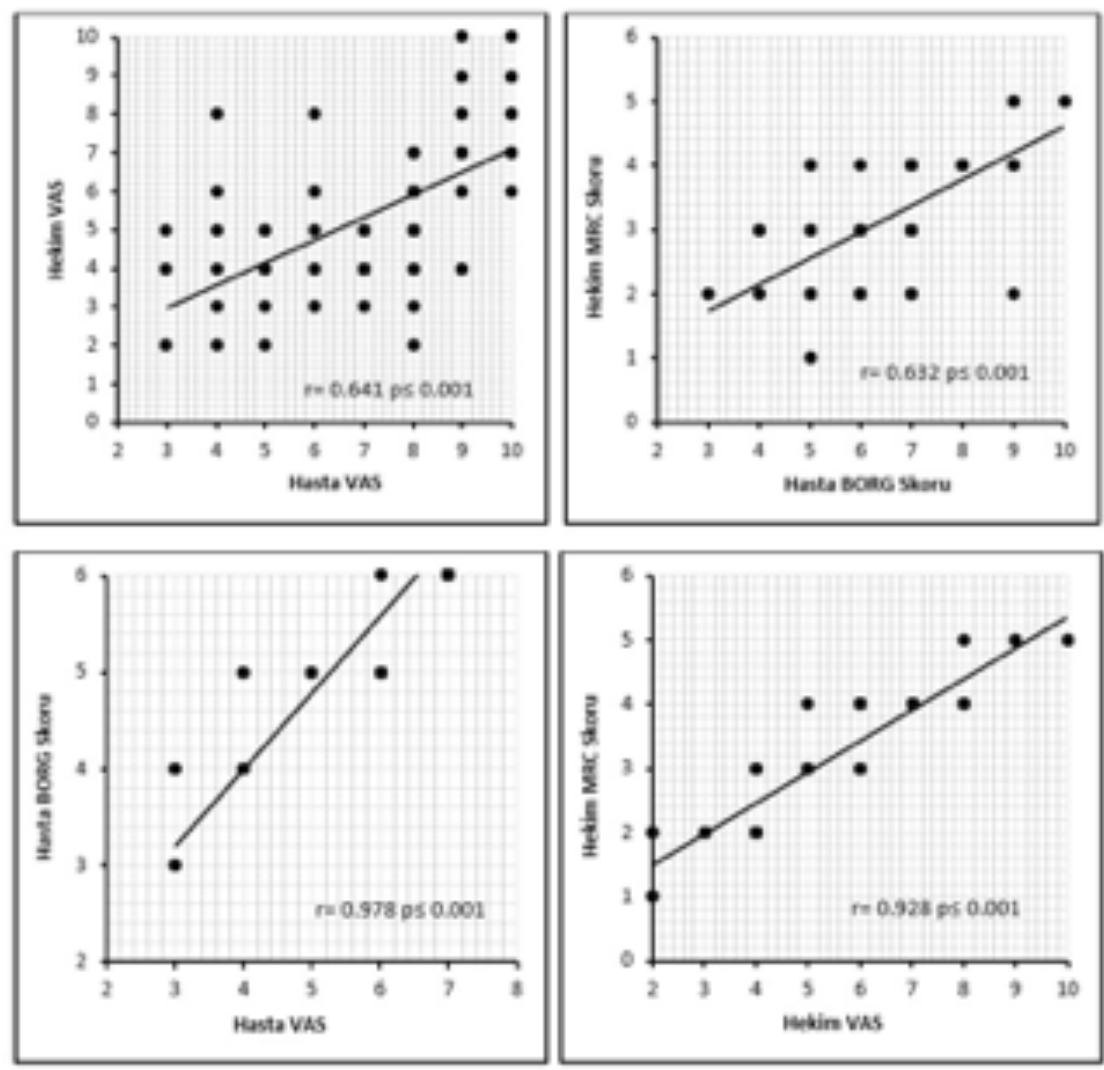

Resim 4. Nefes darlığı şiddetini saptamada kullanılan skalalar ve birbirleri ile korelasyonları.

Tablo 2. Nefes darlığı skorları ve ortalamaları.

\begin{tabular}{lccccc}
\hline & Minimum - Maksimum & Medyan & \multicolumn{2}{c}{ Ortalama \pm standart sapma } \\
\hline Hasta VAS & $3-10$ & 7,0 & 7,1 & \pm & 2,0 \\
Hasta BORG Skoru & $3-10$ & 6,0 & 6,5 & \pm & 1,7 \\
Hekim VAS & $2-10$ & 5,0 & 5,4 & \pm & 2,0 \\
Hekim MRC Skoru & $1-5$ & 3,0 & 3,2 & \pm & 1,0 \\
Hasta-Hekim VAS farkı & $-4-6$ & 2,0 & 1,7 & \pm & 1,7 \\
\hline
\end{tabular}


Tablo 3. Nefes darlığı ölçeklerinde hasta ve hekim ilişkisinin çalışmadaki verilerle karşılaştırılması.

\begin{tabular}{|c|c|c|c|c|c|}
\hline & & \multicolumn{2}{|c|}{ Hasta-Hekim VAS } & \multicolumn{2}{|c|}{ BORG- MRC } \\
\hline & & $r$ & $p$ & $r$ & $p$ \\
\hline Toplam & & 0,641 & $\leq 0,001$ & 0,632 & $\leq 0,001$ \\
\hline \multirow{2}{*}{ Yaş } & $\leq 65$ & 0,413 & 0,032 & 0,444 & 0,020 \\
\hline & $>65$ & 0,722 & $\leq 0,001$ & 0,707 & $\leq 0,001$ \\
\hline \multirow[t]{2}{*}{ Cinsiyet } & Erkek & 0,730 & $\leq 0,001$ & 0,711 & $\leq 0,001$ \\
\hline & Kadın & 0,500 & 0,001 & 0,542 & $\leq 0,001$ \\
\hline \multirow[t]{2}{*}{ Son Durum } & Taburcu & 0,395 & 0,013 & 0,273 & 0,093 \\
\hline & Yatış & 0,706 & $\leq 0,001$ & 0,746 & $\leq 0,001$ \\
\hline \multirow[t]{2}{*}{ Acil Servise Başvuru Şekli } & Ayaktan & 0,560 & $\leq 0,001$ & 0,537 & $\leq 0,001$ \\
\hline & Ambulans & 0,741 & $\leq 0,001$ & 0,729 & $\leq 0,001$ \\
\hline \multirow[t]{2}{*}{ Konsültasyon İhtiyacı } & Var & 0,650 & $\leq 0,001$ & 0,653 & $\leq 0,001$ \\
\hline & Yok & 0,528 & 0,010 & 0,412 & 0,051 \\
\hline \multirow[t]{3}{*}{ Acil Serviste Kalış Süresi } & $\leq 4$ Saat & 0,497 & $\leq 0,001$ & 0,527 & $\leq 0,001$ \\
\hline & $>4$ Saat & 0,814 & $\leq 0,001$ & 0,697 & $\leq 0,001$ \\
\hline & Var & 0,503 & 0,002 & 0,486 & 0,003 \\
\hline Son 1 Ay İçinde Nefes Darlığı İle Hastaneye Başvuru & Yok & 0,700 & $\leq 0,001$ & 0,693 & $\leq 0,001$ \\
\hline \multirow[t]{2}{*}{ Nefes Darlığı Şikayeti İle Hastaneye Yatış Öyküsü } & Var & 0,685 & $\leq 0,001$ & 0,755 & $\leq 0,001$ \\
\hline & Yok & 0,523 & $\leq 0,001$ & 0,426 & 0,002 \\
\hline
\end{tabular}

VAS skorları hem de hasta Borg ile hekim MRC skorları acil serviste kalış süresi $\leq 4$ saat $(r=0,497$, $p \leq 0,001 ; r=0,527, p \leq 0,001)$ ve $>4$ saat $(r=0,814$, $p \leq 0,001 ; r=0,697, \quad p \leq 0,001)$ olan gruplarda anlamlı pozitif korele bulundu (Tablo 3 ). Son bir ay içerisinde nefes darlığı ile hastaneye başvuru öyküsü olan $(r=0,503, p \leq 0,001)$ ve olmayan $(r=0,700, p \leq 0,001)$ hastalarda ve yine bu sebeple yatış öyküsü olan $(r=0,685, p \leq 0,001)$ ve olmayan $(r=0,523, \quad p \leq 0,001)$ hastalarda hasta ile hekim VAS skorları arasında anlamlı pozitif korelasyon gözlendi. Hasta Borg skoru ile hekim MRC skorunda da son bir ay içerisinde başvuru öyküsü olan $(r=0,486, p=0,003)$ ve olmayan $(r=0,693, p \leq 0,001)$ hastalarda ve yatışı olan $(r=0,755, p \leq 0,001)$ ve olmayan $(r=0,426$, $p=0,002$ ) hastalarda pozitif korelasyon saptandı (Tablo 3).

\section{Tartışma}

Çalışmamızda acil serviste hasta ve doktor gözüyle nefes darlığı şiddetini değerlendirmede kullanılan VAS, Borg ve MRC ölçekleri birbirleri ile korele bulundu. VAS ve Borg tek yönlü ölçeklerinde hasta ile hekim arasında uyum olduğu; hasta için VAS değerleri arttıkça Borg değerinin de arttığı ortaya koyuldu. Hekim
MRC skoru hekim VAS ve hasta VAS ve Borg skorları ile koreleydi. 65 yaş altında, kadınlarda, taburcu olanlarda, ayaktan başvuru yapanlarda, konsültasyon intiyacı olmayanlarda, acilde kalış süresi $\leq 4$ saat olanlarda, son bir ay içerisinde nefes darlığı ile hastaneye başvuranlarda ve daha önce nefes darlığı sebebi ile hastaneye yatış öyküsü olmayanlarda korelasyon gücü daha düşük bulundu.

Çalışmamız VAS, Borg ve MRC ölçeklerini birbirleri ile korele bularak bu ölçeklerin birbiri yerine güvenle uygulanabilir ve tercih edilebilir olduklarını ortaya koymaktadır. İster hasta ister hekim gözüyle olsun değerlendirilen nefes darlığı şiddetlerinin birbirleriyle paralellik gösterdiği, bu ölçeklerin birbirleri yerine ve güvenle kullanılabileceği kanısına varılabilir. Ancak ölçeklerde hasta skor ortalamasının hekim skor ortalamasına göre daha yüksek olduğu unutulmamalıdır. Her ne kadar çalışma öncesi bilgilendirme yapılmış ve onam alınmış olsa da hastaların yakınmalarının şiddetini daha yüksek göstererek tedaviye daha erken ulaşabileceği fikri buna sebep olmuş olabilir. Ayrıca hasta kişisel olarak yaşadığı bir problemi yani şikayetini daha önemli hissederek yüksek 
puan işaretliyorken hekim hastanın şikayetini daha önemsiz değerlendirerek daha düşük puan işaretliyor olabilir. Yine değişkenler ile ayrıntılı incelendiğinde skorlar arasındaki bu ortalama farkının aslında gençler, kadınlar, taburcu olanlar, ayaktan başvuru yapanlar, konsültasyon ihtiyacı olmayanlar, acilde kalış süresi kısa olanlar, son bir ay içerisinde nefes darlığı ile hastaneye başvuranlar ve daha önce nefes darlığı sebebi ile hastaneye yatış öyküsü olmayanlardan kaynaklandığı belirlendi.

Bugüne kadar yapılan çalışmaların çoğunda VAS'ın nefes darlığı şiddetini değerlendirmede kullanılabilecek güvenilir bir ölçek olduğu, hatta nefes darlığı şiddetindeki dakikalık değişikliklere bile duyarlı olduğu belirtilmektedir. Yine Borg skalası, ilk olarak 1970 yılında fiziksel egzersiz sırasında harcanan çabanın ölçülmesi amacıyla geliştirilmiş sonrasında ise modifiye edilmiştir. Sıklıkla eforla oluşan nefes darlığının şiddetini ve istirahat halindeki nefes darlığının şiddetini değerlendirmek amacıyla kullanılmaktadır. Çalışmamızda her iki tek yönlü ölçek de kullanılmış ve hasta ile hekim arasında uyum olduğu; hasta için VAS değerleri arttıkça Borg skorlamasındaki değerin de arttığı ortaya koyulmuştur. Bu sebeple birbiri yerine güvenle uygulanabilir ve tercih edilebilir ölçeklerdir. Ancak Modifiye Borg skalası için derecelerine göre nefes darlığı şiddetini tanımlayan on maddeden oluşması ve şiddetin tanımlanıyor olması sebebiyle hastalar açısından daha kolay uygulandığına yönelik veriler literatürde bildirilmektedir. MRC skalası ise ilk olarak Fletcher tarafından, akciğer hastalığı olan kişiler ile olmayanların efor sırasındaki nefes darlığı şiddetlerini karşılaştırma amacıyla kullanılımıştır. Daha sonrasında İngiliz Medikal Araştırma Kurulu (Medical Research Council: MRC), tarafından hastalığın doğal seyrinin izlenmesi amacıyla bu ölçek daha da geliştirilerek kullanıma sunulmuştur. Yine çalışmamızda MRC skoru hastanın işaretleme yaptığı VAS ve Borg skoru ile, hekimin işaretleme yaptığı VAS ile de anlamlı ilişkide bulundu. Skorlar arttıkça MRC skoru da yükselmekteydi ki bu ilişki literatürle de uyumlu idi [1, 4-7]. Ancak literatürde tersi bildirimde bulunan çalışmalar da mevcuttur. Rosi ve ark. astım hastalarının hava yolu obstrüksiyonu ve inflamasyonunda nefes darlığı algılarını araştırmak amacıyla yaptıkları bir derlemede dispne skorlarının değişken yanıtlar ortaya koyduğunu bildirmiş ve bunun da karmaşık fizyolojik mekanizmalar sonucunda ortaya çıkan nefes darlığının sonuçta subjektif bir yakınma olmasına ve birçok faktörden etkilenmesine bağlamışlardır [8].

Nefes darlığı, geriyatrik hasta popülasyonu için de acil servislere başvurunun önde gelen nedenlerinden birisidir [4]. Nefes darlığının objektif kriterlerle sınıflandırılmasının hasta değerlendirmesi, yönetimi ve prognozu üzerinde önemli bir role sahip olması sebepli Yürüktümen ve ark. acil serviste yaşlı hastalar üzerinde yaptıkları çalışmalarında VAS, Borg ve MRC ölçeklerini daha yaygın kullanılmaları, güvenilirliklerinin ve geçerliliklerinin pek çok çalışmada ispatlanmış olması nedeniyle tercih etmişler ve bu ölçekleri güvenle kullanılabilir, laboratuvar ve klinik verilerle ilişkili olarak tanımlamışlardır [2]. Literatürde "kişi ne kadar yaşlı olursa algısı o kadar az doğru olur" denilmektedir [9]. Higgs ve Laszlo 60 yaşını dönüm noktası olarak belirtmişlerdir [10]. Biz bu çalışmada alt grup analizi olarak yaşlı hastalarda ölçeklerin hasta ve hekim arasındaki uyumunu değerlendirdiğimizde 65 yaş altı grupta hasta ve hekim korelasyonunu 65 yaş üstü gruba göre daha düşük bulduk. Bu durum yaşlı hastaların nefes darlığı durumunu genç hastalara göre daha sık tecrübe etmiş olmaları nedeniyle değerlendirmede daha objektif yanıtlara sahip olmalarına bağlı olabilir. Çalışmamızda literatürdeki diğer çalışmalarda da olduğu gibi tüm ölçeklerin sonuçları yaş ve cinsiyetten bağımsız bulunmuştur. Ancak hasta ve hekim sonuçları her iki grupta karşılaştırıldığında her iki cinsiyette de şiddet değerlendirmesinde hasta ve hekim korele bulurken erkek hastalarda korelasyonun kadın hastalara göre daha güçlü olduğu bulundu. Erkek hastalar kadın hastalara göre yakınmalarını daha objektif değerlendirebilmekteydi. Foglio ve ark. egzersiz kapasitesi ve nefes darlığı arasındaki ilişkiyi araştırdıkları bir çalışmada egzersiz düzeyinden bağımsız olarak kadınların her seviyede erkeklerden daha fazla nefes darlığı hissettiklerini bildirmişlerdir [11].

Wilson ve ark. tekrarlayan tecrübe ile birlikte dispne duyarsızlığı algısının artı̆̆ını bildirmişlerdir [12]. Meek ise KOAH'lı hastalarda yaptığı bir çalışmada hastaların tekrarlayan tecrübelerde tecrübesiz grupla kıyaslandığında yakınmayı ifade edişlerinde daha az fark gösterdiklerini (objektif) ancak tecrübesiz grupta 
bu farkın daha fazla olduğunu bildirmiştir [13]. Biz çalışmamızda daha önce nefes darığı nedeniyle hastaneye yatış öyküsü olan yani tecrübesi olan hastalarda korelasyonun daha zayıf olduğunu bulduk.

Çalışmamızda önemli kısıtıııklarımız da mevcuttu. Öncelikle çalışma küçük örneklem sayısına sahipti ve bir eğitim ve araştırma hastanesinde tek merkezli bir çalışma olarak yapıldı. Dolayısıyla bu çalışmanın sonuçlarının günlük pratikte uygulanmasını önermeye yönelik genelleme yapmak mümkün değildir. Etyolojik nedenlere yönelik alt grup (KKY, KOAH, pnömoni vb) analizleri yapılamadı ve bu gruplarda nefes darlığı şiddetini değerlendirmeye yönelik ölçeklerin kullanılmasının sonuçları değerlendirilemedi. Son olarak nefes darlığı şiddeti hasta ve hekim tarafından ölçeklerde tek bir defa işaretleme yapılarak değerlendirildi. Tedavi sonrası yanıt değerlendirilmedi. Dolayısıyla tedavi öncesi ve sonrası işaretlemelerin hem kendi içerisinde hem de birbirleri arasındaki ilişki değerlendirilemedi.

Sonuç olarak acil serviste hasta ve doktor gözüyle nefes darlığı şiddetini değerlendirmede kullanılan VAS, Borg ve MRC skalaları koreledir ve birbirleri yerine güvenle kullanılabilir. Ancak korelasyon gücü 65 yaş altında, kadınlarda, taburcu olanlarda, ayaktan başvuru yapanlarda, konsültasyon intiyacı olmayanlarda, acilde kalış süresi $\leq 4$ saat olanlarda, son bir ay içerisinde nefes darlığı ile hastaneye başvuranlarda ve daha önce nefes darlığı sebebi ile hastaneye yatış öyküsü olmayanlarda daha düşüktür.

Çıkar İlişkisi: Yazarlar herhangi bir çıkar ilişkileri bulunmadığını beyan eder.

\section{Kaynaklar}

1. Meek PM, Schwartzstein RM, Adams L. Dyspnea. Mechanisms, assessment, and management: a consensus statement. American Thoracic Society. Am J Respir Crit Care Med 1999;159:321-340. https://doi. org/10.1164/ajrccm.159.1.ats898

2. Yürüktümen A, Karcıoğlu Ö, Topacoğlu H, Karbek F. Dispne ile başvuran geriyatrik olgularda yakınma şiddeti ile klinik ve laboratuvar verilerinin değerlendirilmesi. Turk J Emerg Med 2009;9:163-168.

3. Kara D, Yıldız H. Dispne semptomunun değerlendirilmesinde dispne ölçeklerinin etkinlikleri ve kullanım sıklıkları. Gümüşhane Üniversitesi Sağlık Bilimleri Derg 2013;2:137-149.
4. Chin MH, Jin L, Karrison TG, et al. Older patients' healthrelated quality of life around an episode of emergency illness. Ann Emerg Med 1999;34:595-603.

5. Hajiro T, Nishimura K, Tsukino M, Ikeda A, Koyama H, Izumi T. Analysis of clinical methods used to evaluate dyspnea in patients with chronic obstructive pulmonary disease. Am J Respir Crit Care Med 1998;158:11851189. https://doi.org/10.1164/ajrccm.158.4.9802091

6. Tanaka K, Akechi T, Okuyama T, Nishiwaki Y, Uchitomi $\mathrm{Y}$. Prevalence and screening of dyspnea interfering with daily life activities in ambulatory patients with advanced lung cancer. J Pain Symptom Manage 2002;23:484-489.

7. Bestall JC, Paul EA, Garrod R, Garnham R, Jones PW, Wedzicha JA. Usefulness of the Medical Research Council (MRC) dyspnea scale as a measure of disability in patients with chronic obstructive pulmonary disease. Thorax 1999;54:581-586.

8. Rosi E, Stendardi L, Binazzi B, Scano G. Perception of airway obstruction and airway inflammation in asthma: a review. Lung 2006;184:251-258. https://doi. org/10.1007/s00408-005-2590-z

9. Cuttitta G, Cibella F, Bellia V, et al. Changes in FVC during methacholine-induced bronchoconstriction in elderly patients with asthma: bronchial hyperresponsiveness and aging. Chest 2001;119:1685-1690.

10. Higgs CMB, Laszlo G. Perception of asthma. In: Adams L, Guz A. eds. Lung biology in health and disease. 1st ed. New York: Marcel Dekker 1996;285-309.

11. Foglio K, Carone M, Pagani M, Bianchi L, Jones PW, Ambrosino N. Physiological and symptom determinants of exercise performance in patients with chronic airway obstruction. Respir Med 2000;94:256-263. https://doi. org/0.1053/rmed.1999.0734

12. Wilson RC, Jones PW. Influence of prior ventilatory experience on the estimation of breathlessness during exercise. Clin Sci (Lond) 1990;78:149-153.

13. Meek PM. Influence of attention and judgment on perception of breathlessness in healthy individuals and patients with chronic obstructive pulmonary disease. Nurs Res 2000;49:11-19. 